\title{
Kyrgyzstan-Turkey Relations: Cooperation in Political and Educational Spheres
}

\author{
Dinara Murzaeva ${ }^{1}$ \\ 1 Department of International and Comparative Politics, American University of Central Asia, St. Bishkek, \\ Kyrgyz Republic \\ Correspondence: Dinara Murzaeva, Department of International and Comparative Politics, American University \\ of Central Asia, 205 Abdymomunov, St. Bishkek 720040, Kyrgyz Republic. E-mail: mdinara@hotmail.com
}

Received: June 18, 2014 Accepted: July 22, 2014 Online Published: August 15, 2014

doi:10.5539/res.v6n3p39 URL: http://dx.doi.org/10.5539/res.v6n3p39

\begin{abstract}
In 1991, Kyrgyzstan gained its independence, and started establishing direct links with the world beyond the Soviet frontier. To conduct foreign relations Kyrgyzstan opened its embassies and/or consulates in almost 30 countries. Turkey is one of the key partners for Kyrgyzstan and plays an important role in the country's foreign relations (Note 1). This article aims to look at the development of Kyrgyzstan-Turkey relations from 1991 till 2012 focusing on the aspects of the political and educational cooperation. Cooperation in the political sphere is studied by looking at official statements at all levels and, participation and collaboration in multilateral structures. As for the educational sphere, the focus is mainly on Turkey's various initiatives such as Turkish schools and universities, as well as student exchange programs that can be seen as one of the 'soft power' tools inevitably promoting Turkish culture and values. The paper shows asymmetric relationship in which Kyrgyzstan seeks to pursue multi-vector policy rendering certain limitations in the relationship. Kyrgyzstan is essentially eager to receive Turkish foreign policy initiatives. Turkish presence in Kyrgyzstan has mostly been confined to spheres of education and economy. This reliance on 'soft power' is attributed to the fact that Turkey seems to, at least for now, lack resources and willingness to challenge Russia, China and USA in the competition for political and military influence in Central Asia.
\end{abstract}

Keywords: Kyrgyzstan foreign relations, Kyrgyzstan-Turkey Relations, Kyrgyzstan Foreign Policy, Political and Educational Spheres of Cooperation, soft power

\section{Introduction}

For the purpose of placing the relations between the two countries in the framework of a particular theory of foreign policy, it is necessary to define foreign policy. Foreign policy refers to goals that two countries (in this paper Kyrgyzstan and Turkey) seek abroad, the values that underline those goals and the means used to pursue them (Kegley \& Wittkopf, 2010-2011). In other words, understanding of Turkey's goals in Kyrgyzstan, values and means used to achieve those goals will shed light to Turkey's foreign policy in Kyrgyzstan and vice versa. Looking at relations between the two countries from this perspective will help to understand the so-called directed dyad and the summed dyads (Note 2).

A nation can secure defined goals of national interest by means of foreign policy during the course of its relations with other nations. Therefore foreign policy involves all activities of a nation by which that nation tries to change or maintain/regulate the behavior of other nations and to adjust its own behavior in the international environment (Ghai, 2004, pp. 233-234). In this regard, to understand what constitutes Turkey's interest in Kyrgyzstan and vice versa is of importance. Modern day literature reveals lack of consensus on that issue. Next, it is vital to understand to what extent relations between Turkey and Kyrgyzstan can be explained by studying national interest and activities of the both states with regard to each other. In this paper activities include official statements, visits, agreements, rhetoric of brotherhood and fraternity, participation and collaboration in multinational frameworks, exchange of experience, aid, investments, and cooperation in the educational sphere.

Perceptions, though being very difficult to study and measure, are of utmost importance as they shape images reflected in bilateral relations. Perceptions may include images that exist among Kyrgyz political elites, Kyrgyz and foreign experts, Turkish and Kyrgyz high officials, intellectuals and other segments of society. I tried to reflect and incorporate in this paper, the perceptions revealed in interviews (both personal and printed), reports, 
articles, book chapters and roundtable working papers. It is beyond the reach of this paper to study the perceptions intensively due to lack of time and resources.

A number of scholars have been studying Kyrgyzstan-Turkey relations focusing on various aspects of bilateral and/or multilateral relations (Bulut \& Aydin, 2011; Akkoyunlu, 2008; Hunter, 2001; Aydın, 1999; Dikkaya \& Keles, 2006; Çetin \& Sertkaya. 2011; Yanik, 2004). However these studies focus mainly on economic or cultural sphere including issues such as investments, trade, or providing the general account of Turkey-Central Asian relations. This study is an attempt to contribute to existing literature by looking at the development of Kyrgyzstan-Turkey relations from 1991 till 2012 focusing the aspects of political and educational cooperation. Cooperation in political sphere is studied by looking at official statements at all levels, interviews, participation and collaboration in multilateral structures. As for educational sphere, the focus of the article is mainly on various initiatives such as Turkish schools and universities, as well as student exchange programs that together with developmental aid can be seen as 'soft power' tools that inevitably promote Turkish culture and values.

This study aims to answer the following research questions: Does the concept of soft power adequately explains the Turkish foreign policy in Kyrgyzstan? The methods employed to answer the research question include conducting personal interviews with diplomats, reading numerous books and articles on Turkish foreign policy, soft power and Turkey-Kyrgyzstan relations since 1991 till present. Search for an adequate theoretical framework for the analysis of Kyrgyzstan-Turkey relations occupies a vital place in this study. For this purpose I studied the 'soft power' concept in order to understand whether it is helpful in explaining the relative success of Turkish foreign policy in Kyrgyzstan. Secondly, a content analysis of leaders' and politicians' public statements at all levels made by both sides (including non-state actors such as Gulen Movement) provide helpful answers to Turkey's state interests in foreign policy. Third, bilateral and multilateral relations are also analyzed via content analysis by looking at official statements, visits, bilateral and multilateral agreements.

For this study, I used the following sources: official statements, speeches, as well as reports published by respective Ministries of Foreign Affairs of Turkey and Kyrgyzstan; articles, book chapters, books in Turkish, Russian, and English languages; interviews that I conducted with various experts, diplomats as well as secondary data. Apart from that I used internet resources such as official web-pages of Kyrgyz-Turkish universities, local, Turkish and international newspapers and journals.

\subsection{Theoretical Framework}

In this section, the paper aims to briefly discuss the notion of soft power by looking at the concept to understand whether it helps to explain the Turkish foreign policy in Kyrgyzstan in particular its educational exchange through state and non-state actors.

Soft power, as defined by Joseph Nye, has been increasingly discussed in international relations literature. Soft power can be defined as entire range of policy options covering governmental statements, declarations, official propaganda, ideas, "long-term propaganda of community discourse" (Chong, 2007, p. 58), in other words, "ability to attract others so that they want what you want" (Nye, 2004, p. 6).

Scholars defined soft power using a variety of resources: use of information (Armistead, 2004), philanthropy (Jenkins, 2007) or diplomacy (Kurlantzick, 2007), "rhetoric, persuasion, and agenda-setting" (Rothman, 2011).

Steven Rothman (2011, p. 50) redefines soft power-hard power dichotomy arguing that potential for using hard power resources to implement soft power and vice versa is important (Note 3). He conceptualizes soft power resting on the availability of resources and the possibility of using those resources to influence the payoffs (preferences) for other states, thereby influencing outcomes (Ibid). This influence may not be from the use of hard power or force but by using other resources such as the media, institutions, educational and cultural exchange. Indeed, for a state to use soft power it must possess sources. It is possible to distinguish international and domestic sources. International sources include: respect for international laws, norms, and institutions; fundamental reliance on multilateralism and disposition against excessive unilateralism; respect for international treaties and alliance commitments; willingness to sacrifice short-run national interests in order to contribute toward the collective good; liberal foreign economic policies. Domestic sources include: culture; pronounced social cohesion; elevated quality of life; freedom; sufficient opportunities; alluring lifestyle; political institutions; democracy; constitutionalism; liberalism/pluralism; a well functioning government; bureaucracy (Gallarotti, 2011, p. 30). Some states may not possess all these sources and use only some of them. A state may also serve as a role model for other states in a variety of ways. For example, symbols of national success can be used; and positive image in the world and within a state where soft power is used are also sources. These can be strengthened by possession of hard power such as strong military forces, well-developed economy, and strong state. Both domestic and international sources of soft power reflect an emphasis on policies and actions that 
display an orientation of justice, collective concern, and rules of fair play.

Other resources worth mentioning are framing and rhetoric. There are two types of framing relevant to soft power that may influence outcomes in foreign policy: normative framing and analytical framing. Normative framing consists of identifying an issue at a moral or emotional level, suggesting that attending to the issue is the right thing to do... [It] involves the creation of a causal story, arranging and connecting the causes and consequences uniquely... Normative framing can appear as appealing to morals or to emotions. Moral framing can affect the behavior of a second actor because the frame can affect the context within which actors look at specific issues. Framing a particular choice as morally right or wrong influences the availability of choices to the other actor, given that the other actor adopts this framing (Note 4) (Rothman, 2011, p. 54).

For example, in an interview the current president of Turkey Abdullah Gul noted:

What matters is not to become a world power. What matters is for a country to have its own standards raised to the highest possible point, enabling the state to provide its citizens with prosperity and happiness. And when I say standards, I mean standards such as democracy and human rights. That is the ultimate objective for Turkey. When you raise your standards, your economy becomes much more powerful and you become a real soft power. Once you accumulate all this know-how and once you succeed in raising and realizing your standards, then you start being followed very carefully by other countries; you become an inspiration for them. And once that happens, what matters is to combine your hard and soft power and translate it into virtuous power -- for your immediate environment, for your region, and for the whole world (cited in Tepperman, 2012).

As seen, Turkey's leadership aspires to inspire other nations by the use of soft power.

As for analytical framing, it refers to establishing an analytical frame in terms of the causes and effects of a problem, the frame can bring some actors into discussion because they become either victims or perpetrators or establish costs and benefits for states (Rothman, 2011, p. 55). States may use variety of mechanisms of soft power influence using their international and domestic resources. Two mechanisms relevant to this paper worth mentioning include norm diffusion and discourse dominance. Norm diffusion presuppose cultural practices, policies, or political ideas that maybe attractive to another nation. These are customs of behavior based on identity given a particular social environment (March \& Olsen, 2004). It occurs through the copying of successful policies or the diffusion of common practices of one country by another country. It may provide a normative feeling that the government is doing something right as opposed to doing something that is a moral or ethical wrong. For example, Abdullah Gul suggested a notion of "a virtuous power" that is not ambitious or expansionist in any sense...it is a power where the priority lies with safeguarding the human rights and interests of all human beings in a manner that also entails the provision of aid to those in need without expecting anything in return... a power that knows what's wrong and what's right and that is also powerful enough to stand behind what's right (cited in Tepperman, Ibid).

Norms can become diffused through the state but also via various groups, NGOs, educational institutions, and non-state actors. The diffusion of norms depends on whether a particular norm is successful at achieving an outcome desired by the party who can choose whether to accept or reject such a norm. In international politics, norms compete and states choose policies which they believe are successful for their goals, and if those policies are successful, the policy will become attractive to others seeking similar goals and most likely adopted by them (Rothman, 2011, p. 59). Discourse dominance assumes visual actions, rhetorical actions, protests, and other factors to capture the attention of the media and change the way the world or particular states discusse a particular issue. Strategically, utilizing a rhetoric or creating a new rhetoric and symbols of a particular discourse allows actors to influence the world, regional or particular state politics, through soft power.

Some authors underline the voluntary nature of compliance and non-coercive methods. It is believed that soft power cultivates compliance through a "variety of policies, qualities, and actions that endear nations to other nations - more indirect and non-coercive methods...Soft power... conditions the target nations to voluntarily do what soft power nations would like them to do; hence, there is far less conflict of interests in the process of soft power" (G. M. Gallarotti, 2011, p. 28). Soft power is called meta-power as power relations themselves are embedded within some greater constellation of social relations that influence those power relations and thereby influence final outcomes that derive from the interactions among actors. The structures of the bargaining boundaries are determined by the processes going on in the greater social relations within which they are embedded (i.e., endogenous rather than exogenous) (Ibid, also see Hall, 1997).

Alan Chong (2007, p. 58) mentions soft power's three operational features: promoting coherent attractiveness of national community, omnidirectionality of audiences, and the need for consistency and credibility of information 
supply that offer spectrum of possibilities of foreign policy outcomes.

Chong (2007, p. 192) believes that soft power can be used by both state and non-state actors. State can use it, along with hard power, by establishing leadership through bounded examples of material, political and cultural success. In this, empirical model to point to is important. Non-state actors can also use soft power if they wish to effect what they perceive as desirable changes in foreign policy (Ibid). Non-state actors may target the state with discourse and with intent of realigning the sense of community embodied by the double boundary of nation and state. Moreover non-state actors may align with the state in use of soft power in such a way that forces favorable to their cause operate successfully.

\subsection{Historical Overview of Relations since 1991}

The relations between Kyrgyzstan and Turkey started in 1991 when Turkey became the first country to recognize Kyrgyzstan's independence. Embassies of both countries in the respective capitals had been set in accordance to the protocol signed on 29 January 1992. On 23 December 1991 the Kyrgyz President Askar Akaev made his first official visit to Turkey and signed a number of agreements with his Turkish counterpart (The Embassy of Kyrgyz Republic to Turkey official web-site [EKRT web-site]). It is generally stated that relations between two countries are based on common history, culture, religion and language, and principles of cooperation between two countries include respect for the international law and the national interests of each state as well as norms of equality and friendship (See, for example, the "Agreement on Eternal Friendship and Cooperation" signed in 1997 by the two governments).

The legal basis of the relations was laid out in 1990 by means of bilateral agreements and protocols in the sphere of political, economic, educational, cultural, trade, scientific research and military cooperation. The total number of agreements reached over 1000 in 2012 and this provides a solid legal basis for present and future cooperation (EKRT web-site; the Ministry of Foreign Policy of the Republic of Turkey official web-site). The majority of these agreements had already been implemented.

The direction and content of the relations between the two countries were determined on 24 October 1997 when the governments of Kyrgyzstan and Turkey signed "Eternal Friendship and Cooperation Treaty" and when they announced to the world a joint statement "Kyrgyzstan and Turkey Together to the 21th Century" on 1 July 1999. These two important documents outline in general terms the direction of cooperation between the countries.

From the second half of 1990s, Turkey has once again re-organized its relations with Kyrgyzstan on the basis of mutual benefit based on the principle of equal sovereignty. In this context, while Turkey has revised the agreements in areas of economy, trade, education, science, culture, sports and others, it also signed new strategic partnerships agreements. At the international arena, Turkey stood by Kyrgyzstan's side and supported Kyrgyzstan's integration into the Euro-Atlantic institutions.

\section{Kyrgyzstan-Turkey Relations: Political Sphere}

\subsection{Turkey in Kyrgyzstan Foreign Policy: Bilateral Relations}

This subchapter aims to answer the following questions: What place does Turkey occupy in Kyrgyzstan's foreign policy? What national interest does Kyrgyzstan pursue with regard to Turkey?

The cooperation with the Republic of Turkey occupies an important place in Kyrgyz foreign policy. If one looks at a number of official visits, documents signed and mutually supportive statements, the relations seem to develop actively. In recent years, in order to take Kyrgyzstan-Turkey relations to a higher level and establish mutually beneficial cooperation, a number of visits from both sides were organized. Especially, during the last two years (2010-2012) the relations between two countries are seen as reaching its peak (Note 5). After the change of regime in Kyrgyzstan in 2010 causing political instability, the Turkish government considerably supported Kyrgyzstan and provided substantial aid. Turkey also supported Kyrgyz government's initiative to establish a parliamentary system in the country. In 2010-2011, in the position of the Prime Minister and by the end of 2011 in the position of th President, Almazbek Atambayev is seen as having close ties with Turkey ("Almazbek Atambayev has not only good relations with Turkish authorities but a successful business too", Kyrgyz News Agency 24. kg; "Speaking very good Turkish, Atambayev noted that it means much from the perspective of showing support for the newly formed Kyrgyz government», Today's Zaman newspaper, 2 February 2011). This shows that relations between two countries will grow and acquire a new dimension at least during his presidency. For example, President Atambayev's first official visit on 11-15 January 2012 was to his "second motherland", Turkey. During this visit, President Atambayev called Turkey a "mother for all Kyrgyz" saying that "Turkey is our Northern Star, and as Turkey grows and develops, it stands as an example for us. It opens the way forward for its brother nations - [Kyrgyzstan]" (Today's Zaman, newspaper, 2 February 2011). 
During his official visit in January 2012 President Atambayev has made a speech in the Grand National Assembly of Turkey. He addressed in Turkish language and the message was positively perceived by the MPs of the Turkish parliament:

In mound Kul Oba in Crimea there is an image found in which two Turk soldiers stand back to back and shoot arrows at enemies. That is the meaning of the word arkadash, the one who protects your back! Ancient Turks always protected the back of each other. So even left alone, they would never give up! It was with this idea the Great Turkic Khaganate was established and existed for 200 years, from 552 to $743[\mathrm{AC}]$. This state had collapsed when the brother started shooting in the back of his brother, a Turk shooting at Turk. The Khaganate territory stretched from the borders of the Great Wall of China to the Black Sea. And the Khanate consisted of all Turkic peoples. It was during the Turkic Khaganate the Turks conquered Central Asia and since then remained in, and preserved Central Asia. A proverb says: "If you fire in the past with a hand gun, the future will shoot at you from cannon!". We must remember and cherish our past and then we will have a bright future. History gave us another chance, if not to build the Great Turkic Khaganate, then at least to build a strong brotherhood of Turkic states. However for this it is necessary that not only Turkey, but also the other Turkic republics firmly stand on their feet, becoming economically developed strong states. They try to make us stand on our knees in exchange for loans and finances for Kyrgyzstan. But we, the Turks, will never become slaves. Because for a Turk it was always better to die standing than live on his knees as a slave (President Almazbek Atambayev speech in the Turkish Parliament (in Russian, 2012).

Evidently, President Atambayev emphasized the historical bond, links between the two nations and uses the brotherhood rhetoric.

During the January 2012 visit, President Almazbek Atambayev and President Abdullah Gul emphasized the strategic nature of relations between the two countries that gradually progress in a many of spheres. As a result, a number of documents were signed including: "Mutual 20th Jubilee Deaclaration on a New Historical Period of Relations between the Kyrgyz Republic and the Turkish Republic" at the presedential level; and - "Plan of Cooperation between the Kyrgyz Republic and the Turkish Republic for 2012-2013" at the level of Ministries of Foreign Affairs (See Presidential web-site in Russian language «Президенты Кыргызстана и Турции подписали юбилейную декларацию о новом историческом этапе отношений между двумя странами», 12.01.2012). Furthermore, the two states exchanged the instruments of the ratification of an agreement on legal assistance. According to Kyrgyz Ambassador in Ankara, Ermek Ibragimov, these documents will provide the basis for the relations between the two countries for the next 10 years (Ibid). Also, many Kyrgyz experts note that these documents took the bilateral relations to a higher level.

As was mentioned above, especially from the beginning of Almazbek Atambayev's presidential term, the mutual diplomatic rhetoric certainly gives an impression of very close relations between the two countries. In one interview, President Atambaev reiterated importance of Turkey as a partner in the time of hardships: "Our relations with Turkey will be different than they were in the past; they will improve. I am expecting a lot of changes [in the relations between the countries] this year. Turkey gave us a $\$ 21$ million loan last year. In addition, Turkey has also wiped out a $\$ 52$ million debt. No other country has done so much to help us" (See Today's Zaman, 15 January 2012). President Atambayev last visited Turkey on 1 October 2012. Apparently President Atambayev was in Ankara to attend a congress of Turkey's ruling Justice and Development (AK) Party. (“Turkish president meets Kyrgyz counterpart”, Easttime Info Agency, October 1, 2012)

One of the mechanisms of political dialogue is taking place within the framework of mutual visits at the level of foreign ministers. Taking into account the current situation, global developments and important trends, such negotiations cover a wide range of topics and reflect on Kyrgyzstan-Turkey cooperation. The mutual dynamics of cooperation and content of political dialogue between the two countries are taking place at the governmental and parliamentary levels of the countries. An important element of the bilateral relations is the cooperation at inter-parliamentary level. For example, the "Parliamentary Group for Cooperation between Kyrgyzstan and Turkey" was established in the Turkish parliament. Accordingly the "Parliamentary Group of Friendship for Cooperation between Kyrgyz Republic and Republic of Turkey" was established in the Kyrgyz parliament. (The speech of the Ambassador of Turkey to Kyrgyz Republic (in Turkish language), 27 March, 2012). Mutual visits at this level take place regularly. For example, on 25-27 September 2011, the Speaker of the Kyrgyz Parliament Ahmatbek Keldibekov paid official visit to Turkey, and as a result "The Memorandum of Cooperation between the Turkish Parliament and the Jogorku Kenesh of Kyrgyz Republic" was signed (See Türkiye Cumhuriyeti Dişişleri Bakanlığı, "Türkiye - Kırgızistan Siyasi İlişkileri” [The Ministry of Foreign Affairs of Turkey, "Turkey-Kyrgyzstan Political Relations"]). These visits play an important role for the bilateral cooperation. 
Together with the cooperation within the international regional organizations, they help to determine certain lines of cooperation. In this sense, the political and diplomatic activities, the government working programs at the international platforms, mutual official visits as well as documents signed as a result of these visits play an important role.

\subsection{Cooperation within Framework of Multinational Structures}

On the international arena, the political and diplomatic cooperation between Kyrgyzstan and Turkey takes place at multiple levels such as OSCE, the Organization of Islamic Cooperation (OIC), Conference on Interaction and Confidence Building Measures in Asia (CICA), and Turkic Speaking States summit, where the leaders of both countries have the opportunity to cooperate on the various topics. One of the frameworks for cooperation takes place within the relatively recently established Cooperation Council of Turkic Speaking States (CCTS) (Note 6). Sometimes seen as an attempt to integrate Turkic states into a possible Commonwealth of Turkic Nations, the organization in fact is the result of increasing contacts among leaders of Turkic speaking countries and is used as a framework for expansion of bilateral and multilateral ties between its members. Each member may want other members to provide support on a particular issue. For example, Azerbaijan stresses the importance of the fact that Turkic states share the same stance within international organizations and support Azerbaijan`s territorial integrity (See "An international conference on the parliamentary democracy in the development process of interstate relations." available at http://www.turk-pa.org/news.php?id=193\&lang=en).

Interestingly, CCTS also functions as an umbrella organization for existing cooperation mechanisms such as the Parliamentary Assembly of the Turkic Speaking Countries (TURKPA), the International Organization of Turkic Culture (TURKSOY) and Turkic Business Council. Therefore both Kyrgyzstan and Turkey develop their relations in various spheres within the frameworks of these mechanisms of cooperation. Political cooperation also takes place within the Parliamentary Assembly of the Turkic Speaking Countries (TURKPA), whose goal is "to strengthen relations between the Turkic-speaking countries and support Turkic-speaking countries in international organizations, as well as to help them share their experiences in legislative processes" (See "Press conference on annual activities of TURKPA", 17.04.2012). The cultural cooperation continues via the operation of TURKSOY, and the strengthening of business is pushed within the activities of Turkic Business Council.

CCTS has the following goals: Strengthening of the mutual confidence among the Parties; maintaining peace in the region and beyond; promoting the common positions on foreign policy issues; coordinating actions to combat international terrorism, separatism, extremism and trans-border crimes; promoting an effective regional and bilateral cooperation in all areas of the common interest; creating favorable conditions for trade and investment; aiming for a comprehensive and balanced economic growth, social and cultural development; discussing questions of ensuring the rule of law, good governance and protection of human rights; expanding interaction in the fields of science, technology, education and culture; encouraging interaction of the mass media and wider communication; promoting the exchange of legal information and enhancing legal cooperation (CCTS official web-page at http://www.turkkon.org/eng/icerik.php?no=31).

Even if these declared goals are not realized at present as member-states hold different views on certain issues, the CCTS offers opportunities for dialogue through regular meetings at different levels, including levels of the heads of states, ministers, senior officials. These meetings and summits bear potential for cooperation in a number of spheres as well as an opportunity to elaborate a common position on certain issues. At these conferences Kyrgyz representatives keep on reiterating the positive nature of cooperation in such frameworks. For example, at the I Plenary Session of TURKPA, Aitybai Tagayev, the former Speaker of Jogorku Kenesh of the Kyrgyz Republic, stated:

Assembling the parliaments of fraternal countries with the same historical roots, common culture and language, TurkPA makes an important step towards the establishment of the significant international organization. Therefore, we have no doubt that this Assembly will become one of the important organizations. The world economic crisis has shown itself everywhere, as well as in our country. In my opinion the maintenance of trade and economic relations of TurkPA member countries is one of the important matters. In short, we have to unite our efforts and take joint actions in order to solve these issues. Rational use of economic facilities of the Turkic-speaking countries is very important for the purpose of developing cooperation in the spheres of trade, economy and investment. The future achievements of the Assembly will be an example not only for the world but also for our people. The multilateral relations in the cooperation are very important for the strengthening of mutual bilateral relations. The investigation of applying the interstate mutual decisions of the Turkic-speaking countries and acquisition of statistical information should always be under the control of TURKPA General 
Secretariat (Speech of Mr. Aitybai Tagayev, Speaker of Jogorku Kenesh of the Kyrgyz Republic at the First Plenary Session of TURKPA, 23.05.2012).

Though the speaker did not mention how to fight world economic crisis, he emphasized importance of cooperation with TURKPA's members for Kyrgyzstan'. This also includes enhancing the inter-parliamentary cooperation. For example, TURKPA has conducted an experience-exchange program among the parliaments of Kyrgyzstan and Turkey. This process is continuing and has brought positive results. Similarly other member-states (partners within TURKPA) maintain similar views. During the III Plenary Session of TURKPA in Bishkek on 14-15 June 2012, TURKPA General Secretary stated: "TURKPA gives particular importance to strengthening a common inter-parliamentary platform for the dialogue at a global level. TURKPA believes that parliamentary diplomacy, as complementing the traditional diplomacy, will play particular role in strengthening peace, democracy and economic development the world over. TURKPA's close cooperation with the international institutions of Asia and Europe is crucial in intensifying the inter-cultural and inter-faith dialogue between the civilizations and highlighting the issue of tolerance, being a basic factor in the world agenda" (Speech of Mr. Ramil Hasanov, TURKPA Secretary General, 25.06.2012). This also can be seen as 'institution-building, capacity-building, finally democracy-building efforts'.

However, some experts such as Moldobaev (2010) maintain that at present the activities of CCST bear mainly "declarative character" and it is visible that "many documents bear pro-Turkey vector."

\subsection{Kyrgyzstan in Turkey's Foreign Policy}

After spending the Cold War as a buffer state, Turkey felt the need to redefine its role on the international arena in the aftermath of the Cold War. The emergence of the Central Asian republics played an important role in this process of redefinition (Yanik, 2004, p. 293).

In the first years of their independence, Turkey was actively promoted as a "model of development" for Central Asian countries with predominantly Muslim population (Note 7). According to Yanik (2004) "Turkish foreign policy is more active in regions such as the Middle East where there is ample scope to play a regional leadership role." Therefore Turkish foreign policy is less active in regions such as Central Asia where the scope for regional leadership is more limited and would be contested by powerful rivals such as Russia. However since mid-2000 Turkey attempted to play a more active regional and global role with particular emphasis on helping to promote cross-cultural dialogue and performing a mediating role in major regional and international conflicts (Öniş, 2010).

At the official and formal levels, Turkey sees Kyrgyzstan as a friendly state and an important partner in Central Asia. As was often mentioned by Turkish President Abdullah Gul, Prime-Minister Reccep Erdogan, and the high level Turkish officials, Kyrgyzstan is an important country located at the most strategic place in Central Asia. The Turkey's position can be seen in the speech of Cemil Cicek (2012), the speaker of Turkish Parliament:

Our country has strong bonds with Kyrgyzstan and it is our earnest desire that Kyrgyzstan maintain its independence and stability. The Turkish-Kyrgyz ties cannot be seen as merely relations between two states. Rather, we are people who are the branches of the same tree. Our ties are of those between two brothers. Our relations are not guided by interests, but by camaraderie, fraternity and friendship. We look in the same direction and nurture the same feelings. Improving these fraternity-based ties in every field will be of benefit to both of our nations.

It must be noted that the two largest rival political parties in Turkey maintain similar positions on Turkey's relations with Central Asian states and emphasize a need for stronger ties with them, particularly with Kyrgyzstan. The position of Turkey's ruling Justice and Development Party (AKP) is well-known for their goals of greater relations and stronger ties with Kyrgyzstan. As for the Republican People's Party (CHP), their foreign policy stance is that Turkey must strengthen relations with Central Asian states in all spheres. (See Program of the Turkey's Republican people Party (Cumhuriyet Halk Partisi Programı). Çağdaş Türkiye için Değişim.) CHP is against a loss of sovereignty of the Turkic republics that gained independence after the dissolution of the Soviet Union. However, the means of deepening of the relations may be seen differently (Note 8).

The Turkish foreign policy under the AKP administration has been associated with the name of Ahmet Davutoğlu who was the chief foreign policy advisor for the Prime Minister Recep Tayyip Erdoğan before he was appointed foreign minister in 2009. Davutoğlu outlined his foreign policy doctrine in several writings, the most important of which is his book "Strategic Depth" (2000). According to this doctrine, Turkey possesses a "strategic depth" due to its history and geographic position, and it is among a small group of countries with so-called "central powers". Turkey should not be content with a regional role in the Balkans or the Middle East, 
because it is not a regional but a central power. Hence, it should aspire to play a leading role in several regions, including Central Asia, which could award it global strategic significance (Grigoriadis, 2012, p. 4) Therefore, Turkey should develop a proactive policy commensurate to its historic and geographic depth, which is amplified by its Ottoman legacy. To achieve that aim, Turkey should capitalise on its soft power potential. This is based on its historic and cultural links with all the regions which it belongs to, as well as its democratic institutions and thriving market economy. Turkey needs to put aside its militaristic image underpinned by history of military tutelage over society. Instead, it should promote conflict resolution and regional economic cooperation (Ibid).

As it was proclaimed by Ahmet Davutoglu (2012), the current Minister of Foreign Affairs of Republic of Turkey: "Turkey's reintegration with its neighbors is asset for its foreign policy in this turbulent era... One strength of our foreign policy is the "ongoing reintegration with neighbors as well as reconnecting with the people ....with whom we share a common history." Kyrgyzstan is seen as a nation with which Turkey shares a common history. Therefore the Strategic Depth doctrine explains Turkey as a power that aims to continue increasing its influence in Central Asia and Kyrgyzstan. Among Turkey's goals there can be seen an attempt to regain, strengthen and exercise influence over the Turkic republics of Central Asia, including Kyrgyzstan.

However, Weitz (2011) observes that the views concerning the future political developments in Central Asia that shape foreign relations with Turkey differ among Turkish government officials and analysts. One group sees Central Asia as "the last bastion of one-party authoritarian rule and consider the prospects for its near-term democratization to be high. This group welcomes a phenomenon like the Arab Spring in the region since they consider the absence of functioning democracies in most Central Asian countries a significant problem for Turkish entities" (Ibid) .The reason is that "since a single individual or group determines all major policies in a dictatorship, authoritarian governments are prone to making radical changes in policy overnight" (Ibid). In addition, with authoritarian regimes, access to information and legal arbitrariness present major obstacles to domestic and foreign entrepreneurs seeking to run profitable businesses. This view partly explains why this group welcomed the regime change and democratization in Kyrgyzstan in 2010.

But another group of Turkish officials consider the prospects for Central Asia's near-term democratization to be low. In the view of these Turkish analysts and officials, another constraint on political change in Central Asia is the geographic isolation of these states from other democratic countries as well as their history of authoritarian rule. They argue that Central Asia's democratization would entail a lengthy process requiring the further political and economic evolution of these countries. Conversely, this second group of Turkish officials fear that efforts to rush Central Asia's democratization could easily backfire leading their rulers to adopt even more repressive domestic policies.

Weitz (2011) believes that despite their differences, both groups of Turkish officials maintain that their country could play at best a modest role in Central Asia. Neither considers Turkey sufficiently powerful to compete with Russia or USA directly for the regional influence. Turkish officials recognize Russia's political, military, and economic primacy in Central Asia. They also view China as a growing economic power in the region. These officials see Turkey's role in Central Asia mainly in cultural terms, encouraging the Turkic peoples to learn Turkish and acknowledge their historical affinity with the commonwealth of Turkish nations. They also want Turkish businesses to trade and invest in the region. In practice, the few Turkish companies having a major presence in Central Asia concentrate their activities in certain economic sectors such as construction.

To sum up, Kyrgyzstan does not occupy the first place in Turkish foreign policy, comparing to European Union, Middle East, and the USA. Therefore the relations with Kyrgyzstan are sometimes described as "romantic." (Author: Interview with a faculty member of Kyrgyzstan-Turkey Manas University. 23.10.2012, Bishkek). It implies that even though Turkey keeps on investing, providing assistance, and spending on various projects such as Kyrgyzstan-Turkey Manas University, the output or effect of all these initiatives are rather vague. Turkey's image in the country, among both political elites and other segments of society, Turkey's influence on regional politics, on Kyrgyzstan's foreign policy, and others is yet to be carefully assessed. The answers to these questions may affect the manner in which Turkey would build its relations with Kyrgyzstan in the future. Undoubtedly Turkey-Kyrgyzstan relations will continue but the costs of further deepening of influence may change Turkey's strategy toward Kyrgyzstan.

As for Kyrgyzstan, as a country in need (need of not only financial resources, but also Turkey's experience in many spheres, including business, state-building, banking, education system, and many others.), it will maintain friendly relations with Turkey. However, Kyrgyzstan's leadership also needs to change the way it sees Turkey by focusing on mutually beneficial cooperation (not only "receiving part" with high expectations), that would promote national interest. 


\section{Cooperation in the Sphere of Education}

As was already mentioned, Turkey's active involvement in educational sphere of Central Asian states can be seen as a result of redefinition of Turkey's foreign policy in early 1990s. This redefinition included the highlighting of Turkey's common ethnic bonds with the Turkic republics of the former Soviet Union. Turkey emphasized common history and traditions, attempted to create a common alphabet, and went further to create and reorganize certain existing institutions that worked to highlight this ethnic commonality. The educational ties established with Kyrgyzstan were an important part of this cultural reorientation policy pursued by Turkey. Turkey's initiatives to promote cultural cooperation, Turkish language, Turkish schools and universities, occurred at two levels, state and non-state. The focus of this subchapter is to analyze these initiatives as well as student exchange programs.

It is well known that education is one of the important tools for the purpose of protection of cultural values. Educational exchange can also be seen as a tool of "soft power", when one country (or international actor) gets other countries to want what it wants (Nye, 1990, p. 166). It allows a nation that uses soft power to get what it wants indirectly. As Joseph Nye (2004) notes, "a country may obtain the outcomes it wants in world politics because other countries - admiring its values, emulating its example, aspiring to its level of prosperity and openness - want to follow it." Educational exchange can be seen as foreign policy tool as well. Educating Kyrgyzstan's youth had two very important goals. First, educating today's students contributes to the creation of the elites of tomorrow who later would be in charge of the transformation in their country (quoted in Yanik, 2004). Secondly, the goal was to create a stratum of people who would be well versed in Turkish culture and language, who then would act as a bridge between their countries and Turkey. The students coming out of this educational experience were expected to bear the 'Turkic identity' that the Turkish elites thought was in the making since the Turkic republics gained their independence in 1991. Turkish officials were quick to realize the importance of education as a powerful mechanism of identity creation and social change (Yanik, 2004, p. 294).

Therefore Turkey established public and private educational ties with Kyrgyzstan. Kyrgyzstan-Turkey relations in the educational sphere are at two levels: at an official level with state initiatives and activities, and a civil society level. Indeed, since Kyrgyzstan's independence Turkey has been actively involved in the educational sphere. Beteen 1992 and 2012 more than 100 agreements and protocols of cooperation in the sphere of education, science and culture were signed between the two states. On the basis of these agreements, the common project "Big Student Project" (Büyük Öğrenci Projesi) was launched in 1992 marking the beginning of the cooperation in the sphere of education. Within the framework of inter-governmental agreement of student exchange, 2000 students from Kyrgyzstan pursue education in Turkey's universities at present (Embassy of Republic of Turkey in the Kyrgyz Republic). They study under the scholarship scheme. Accordingly, more than 1000 Turkish students study in the Kyrgyz universities (Author Interview with Deputy Chief of Mission, Mr. Seyfullah Sahin, 25.04.2012, Embassy of Republic of Turkey, Bishkek).

On 30 September 1995, the governments of Republic of Turkey and Kyrgyz Republic signed the agreement on establishment of Kyrgyz-Turkish Manas University that was followed by approval of the competent authorities of both countries. Manas University plays an important role in strengthening of the relations between the two countries in the educational sphere. For example, during his official visit in February 2011 to Kyrgyzstan, Prime-Minister R.T. Erdogan noted that Turkish state investments into Kyrgyz-Turkish Manas University reached US\$ 150 million. The mission of the university states: "Aiming that the individuals from all over the world, primarily from the Turkic Republics and Turkic Nations, learn together and create a common understanding, and therefore to contribute to the world's science primarily to the Turkish Civilization, training up individuals who are competent in their subject and self-confident, who are equipped with universal values, moral principles and with the knowledge of being Turk in the frame of our common culture, and who are aware of their social responsibilities, are contemporary and who may be internationally employed." (See Manas University official web-site: http://www.manas.kg/index.php/en/niversity/our-mission). At present, almost 5000 students study in Manas University. The university is a quite prestigious educational institution in Kyrgyzstan that provides education free-of-charge on merit-basis and has excellent educational facilities. It is the only university that has a large campus.

Horizontal links of cooperation have emerged among the largest universities of the two countries. For example, exchange of information, training of faculty members as well as exchange of experience of scientific research is on the way. One of long-term inter-university collaboration exists between Ankara University and Bishkek Humanitarian University; Osh State University and Marmara University etc. ("Diplomatic Relations between Kyrgyzstan and Turkey are 20 years", Embassy of Kyrgyz Republic in Turkey, 02.02.2011). 
The so-called civil-society initiatives come from non-state actors such as various foundations, especially ones known to have ties to the Nurcu community of Fetullah Gülen. Fethullah Gülen movement (Note 9) in Kyrgyzstan is represented by Sebat International Education Institute (Sebat), the founder of the Kyrgyz Turkish Schools (Keles, 2009). It is a non-governmental organization established in the Kyrgyzstan in 1991. Since February 1992, Sebat has opened 15 high schools, 4 university dormitories, the International Ataturk Alatoo University, the International Silk Road School, and the Secom Center for language and computer studies. Till today, US\$ 60 million has been invested in education by Sebat. Sebat Institute explains its presence as follows:

Central Asian countries gained their independence in 1991, and a transition period has started not only in political life but in social, cultural and economic lives as well. As a result of this transition, people needed to re-identify their values. Their values were defined under the Soviet System and the result was not so successful. Additionally, there is disunity with Turkic-Islamic values. Kyrgyz Turkish Schools were opened by Turkish entrepreneurs at that time, and local people met with people who possessed a similar set of values. This closeness resulted in many high schools and universities being established in the region (Ibid, Emphasis added).

These educational institutions enjoy popularity due to high quality of education, absence of corruption, discipline and good facilities such as dorms, libraries, teaching faculty and staff. Though schools are private they are popular among Kyrgyz people and many families prefer Turkish schools to Kyrgyz schools. The success of "Sebat" is explained as follows:

The quality of the education together with positive attitudes of teachers toward the students and parents make these schools very successful. The students learn to speak four languages (English, Russian, Turkish and their local language) as well as computer skills and receive many awards from local and international scientific competitions. These activities improve the quality of their education (Ibid).

In general, it can be said that Turkey with its educational standards, provided Kyrgyzstan with good example and considerable support in times when previous Soviet system of education was almost destroyed, and quality of education deteriorated while Western education was not affordable to many.

Furthermore the atmosphere of multi-ethnic, multi-national environment that exists in these educational institutions helps the people of two countries to get to know each other better, learn common historical, cultural heritage and values of the two fraternal states. They also provide opportunities to study languages of the two states, enriching their experience, learning literature, way of life and way of thinking of the two nations. Therefore regardless of its inevitable spread of culture, values and practices, Turkey's involvement in the educational sphere of Kyrgyzstan can be seen as rather positive.

It is argued that the followers of Fethullah Gülen play important unofficial role in promoting Turkish interests in Kyrgyzstan underpinned by the philosophy "based on synthesis of Turko-Ottoman nationalism rather than Islam" (Larrabee, 2003, p. 124). They play a major role in transmitting Turkish cultural values in Kyrgyzstan and it is believed that their influence maybe even greater than that of official Turkish policy (Ibid).

\section{Conclusion}

Turkey is attempting to expand its influence in Central Asia and in Kyrgyzstan but has limited success due to reasons of both domestic and internationalnature. One of domestic reasons is that "Turkish Model" with emphasis on democracy, rule of law, and market economy had found little enthusiasm at least in 1990s and 2000s as Kyrgyzstan was ruled by authoritarian leaders interested in maintaining personal power. At present with Kyrgyzstan moving toward parliamentary system (since 2011) Turkey has re-emerged as a model state in which this system worked more or less successfully for 80 years. However, another domestic reason is that there was and continues to exist a fear on the part of Central Asian and Kyrgyzstan's elites that is Pan-Turkism. Officially, Turkey has eschewed any effort to promote Pan-Turkism. Indeed non-state groups advocated cultural union encompassing the Turkic states of Central Asia and the Caucasus (Larrabee, 2003, p. 123). Perhaps the Cooperation Council of Turkic Speaking States is seen by some as old idea in a new form. International constrains include lack of resources and probably willingness to challenge Russia, China and USA in the competition for political and military influence in Central Asia.

If to assume that foreign policy is direct outgrowth of domestic politics, to be precise domestic needs then such perspective may be useful to understand Kyrgyzstan leadership's stance toward relations with Turkey. Kyrgyzstan sees Turkey as a country that can be helpful to solve Kyrgyzstan's domestic problems. This perspective helps to understand Atambaev's speeches as well as his goal of securing long-term relations and long-term cooperation as there is a clear link between the state's domestic situation and state's foreign policy 
behavior. Therefore there is rather asymmetric relationship in which Kyrgyzstan seeks to pursue multi-vector policy so there are limits on the relationship. Kyrgyzstan is essentially eager to receive Turkish foreign policy initiatives.

As it is often reiterated by Turkish leaders, for Turkey, Kyrgyzstan is important state in Central Asia with which it will maintain friendly relations in future. On the high (official) level the relations have acquired dynamism, through multiple visits, statements, fraternity rhetoric, state developmental aid (Note 10) (TIKA, grants), there is another level of relations that takes place through civil society involvement in foreign policy initiatives (non-state actors such as Sebat Institutes (sphere of education)), small and medium entrepreneurs, Turkish capital in economy of Kyrgyzstan and joint business initiatives. It seems that both state and non-state actors follow the same direction. The involvement of the Nurcu community as a non-state actor in this educational exchange indicates a degree of delegation in the process of creating a collective Turkic identity. Civil society involvement in foreign policy initiatives becomes increasingly important.

The concept of soft power is at least partly explanatory as it is both observable in Turkey's educational and cultural exchange policy and understandable as Turkey lacks and perhaps is unwilling to spend resources to use hard power in its foreign policy towards Central Asia. Use of soft power though statements, declarations, rhetoric of fraternity, brotherhood, ideas seems to be both cheaper and effective in the long term. However it should be mentioned that even the use of soft power presupposes expenditures such as educational exchange. Turkey is being perceived as a friendly state, a reliable partner, developed country with Muslim population and democratic system from which Kyrgyzstan should learn. The normative framing and rhetoric seems especially explanatory as it can be deduced from the Abdullah Gul's statement in which Turkey is portrayed as inspiration to others as $a$ country that is doing right. As a "virtuous power", moreover the norm diffusion is also a part of soft power mechanism that is observable in Turkey's foreign policy toward Central Asia, and Kyrgyzstan particularly. The norms are diffused by both state and non-state actors. Turkish educational institutions openly state the aim of creating or re-creating the identity of new generation of Kyrgyz in their missions. Turkish schools and universities, as well as student exchange programs can be seen as one of 'soft power' tools inevitably promoting Turkish culture and values. Here constructivist theory seems useful to explain how constructed identities, shared knowledge and norms can generate source of action, including foreign policy initiatives. For constructivists, actors' abilities to persuade others through debate, discourse about values to accept their ideas, and acquire new understanding is central. From this perspective, Turkey attempts to create a culture of shared understandings through their cultural foreign policy initiatives.

This reliance on 'soft power' is attributed to the fact that Turkey seems to, at least for now, lack resources and willingness to challenge other big powers in the competition for political and military influence in Central Asia.

Turkey's active involvement in educational sphere can be seen as a positive process for Kyrgyzstan (aid, good quality of education, new approaches, and absence of corruption, discipline and good facilities such as dorms, libraries, teaching faculty and staff). Moreover, it can be added that Turkish language helps many young Kyrgyz students to get jobs either in Turkey, in Russia (construction sector) or in Turkish companies around the world as well as in Kyrgyzstan. Since 1991, the number of students graduated from Turkish universities became high, and these students return to Kyrgyzstan bearing culture, values, attitudes acquired during their studies. This effect of exchange programs is yet to be assessed but undoubtedly there is a "new generation" whose world views are formed in this process. For Turkey, all these educational ties, both public and private, can be regarded as a long-term investment. The success of this investment will only be determined in the coming decades. Due to the initiatives in the educational sphere Turkey acquired a positive image in Kyrgyzstan. Turkey's initiatives and investments in education together with developmental aid can be seen as "soft power" initiatives.

What soft power concept fails to explain is whether all Turkey's initiatives in Kyrgyzstan eventually will result in Kyrgyzstan wanting what Turkey wants in regional and international arena. If to assume that eventually Turkey will get other countries (in this paper Kyrgyzstan) to want what it wants thorough the use of soft power, obtaining the outcomes it wants in world politics because other countries - admiring its values, emulating its example, aspiring to its level of prosperity and openness - want to follow it, then the question is how it is to be measured, observed, and proved. Will it be seen in the creation or re-creation of pro-Turkey future elites that share same values as the Turkey's elites, or citizens in general is to be looked at because finally elites are those who influence decision-making or have chance to become the leader of the state. In other words the question remains unanswered that even if soft power initiatives will be successful in the long-run, how should it be determined, and concluded that it is a result of soft-power policies and not of some other factor. 


\section{Acknowledgements}

First and foremost, I would like to thank the Academic Fellowship Program (in Kyrgyzstan), the Open Society Foundations for its support during my fellowship (2012-2013). Secondly, I would like to thank Dr.Marko Zilovic (University of Belgrade) and Prof. Roland Dannreuther (University of Westminster) for their valuable advice and guidance during the preparation of this paper. Finally, I would like to express gratitude to Ambassador Aydin Idil, for interview on the Kyrgyzstan-Turkey relations.

\section{References}

24. kg. Newspaper. Retrieved from http://www.24.kg/parlament/140428-olga-lavrova-kyrgyzstan-v-tekushhem -godu-poluchit.html

Abdyldaev, Erlan. Roundtable. Kyrgyzstan's Foreign Policy Priorities, 12.04.2012, (in Russian). Retrieved May 5, 2012, from http://www.ipp.kg/ru/news/2326/

Akkoyunlu, S. (2008). The Impact of Turkey's Domestic Resources on the Turkic Republics of the Caspian Sea. European Journal of Economic and Political Studies, 1(2), 1-18.

Almazbek Atambayev has not only good relations with Turkish authorities but a successful business too. Kyrgyz News Agency 24.kg. Retrieved from http://eng.24.kg/politic/2012/03/09/23320.html?print=yes

Ambassador of Turkey to Kyrgyz Republic speech (in Turkish language), 27 March, 2012) /Büyükelçi Akçal'ın "Bağımsızlığının 20. Yılında Kırgızistan-Türkiye İlişkileri" konulu Sempozyum'da yaptığı konuşmanın metni. Retrieved from http://biskek.be.mfa.gov.tr/ShowAnnouncement.aspx?ID=147680

An international conference on the parliamentary democracy in the development process of interstate relations. Retrieved October 23, 2012, from http://www.turk-pa.org/news.php?id=193\&lang=en

Armistead, L. (2004). Information Operations: Warfare and the Hard Reality of Soft Power (1st ed.). Washington, DC: Brassey's.

Auelbaev, B. (2012). Kazakh Institute for Strategic Studies. Russian and Kazakh Experts on Kyrgyzstan Foreign Policy. Retrieved September 25, 2012, from http://www.ipp.kg/ru/news/2212/

Ахматбек Келдибеков «Офиииальный визит парламентской делегаиии в Туриию был успешным», 29 сентября, 2011. Retrieved April 5, 2012, from http://kant.kg/2011-09-29/axmatbek-keldibekov -oficialnyj-vizit/

Aydın, M. (1999). New Geopolitics of Central Asia and the Caucasus Causes of Instability and Predicament. SAM Papers.

Aydın, M. (2007). Türkiye'nin Avrasya Macerası, 1989-2006. Nobel Yayın Dağıtım, 1. Basım.

Baktygulov, Sheradil. Roundtable "Kyrgyzstan's Foreign Policy Priorities", Institute of Public Policy, (in Russian). Retrieved April 5, 2012, from http://www.ipp.kg/ru/news/2326/

Bogatyrev,Valentin. Roundtable. Kyrgyzstan's Foreign Policy Priorities. Institute for Public Policy, 12.04.2012, (in Russian). Retrieved April 7, 2012, from http://www.ipp.kg/ru/news/2326/

Bulut, M. \& Aydin, R. (Eds.) (2011). Economic, Political and Cultural Cooperation in Caucasus and Central Asia. Adam, Ankara, Turkey.

Büyükelçi Akçal'ın "Bağımsızlığının 20. Yılında Kırgızistan-Türkiye İlişkileri. konulu Sempozyum'da yaptı̆̆ konuşmanın metni, 27.03.2012. Retrieved September 8, 2012 from http://biskek.be.mfa.gov.tr /ShowAnnouncement.aspx?ID=147680

Chong, A. (2007). Foreign Policy in Global Information Space: Actualizing Soft Power. Basingstoke, Palgrave Macmillan.

Çiçek, C. (2012). Turkish-Kyrgyz relations are based on fraternity”, 13 June 2012, Today's Zaman. Retrieved from http://www.todayszaman.com/newsDetail_getNewsById.action?newsId=283450

Cooperation Council of Turkic Speaking States official. Retrieved from http://www.turkkon.org/eng /icerik.php?no=31

Состав Депутатской группы дружбы Жогорку Кенеша Кыргызской Республики по сотрудничеству с Турецкой Республикой. Retrieved April 11, 2012, from http://kenesh.kg/RU/Articles/5098-SOSTAV _Deputatskoj_gruppy_druzhby_ZHogorku_Kenesha_Kyrgyzskoj_Respubliki_po_sotrudnichestvu_s_Turec koj_Respublikoj_.aspx 
Davutoğlu, A. (2000). Strategic Depth: Turkey's International Position. Küre Yayinlari, Istanbul.

Davutoglu, A. (2012). Principles of Turkish Foreign Policy and Regional Political Structuring. Republic of Turkey Ministry of Foreign Affairs, Center for Strategic Research (SAM), No: 3, April.

Dikkaya, M., \& Keles, I. (2006). A Case Study of Foreign Direct Investment in Kyrgyzstan. Central Asian Survey, 25(1-2), 149-156. http://dx.doi.org/10.1080/02634930600903213

Diplomatic Relations between Kyrgyzstan and Turkey are 20 years. Embassy of Kyrgyz Republic in Turkey, 02.02.2011. Retrieved May 5, 2012 from http://kgembassy.org.tr/cp-news-detail-in.php?ilan_id=263

Diplomatic Relations between Kyrgyzstan and Turkey are 20 years", Embassy of Kyrgyz Republic in Turkey, 02.02.2011. Retrieved May 5, 2012 from http://kgembassy.org.tr/cp-news-detail-in.php?ilan_id=263

Embassy of Republic of Turkey in the Kyrgyz Republic. Retrieved from http://bishkek.emb.mfa.gov.tr

Erol, M. S. (2007). Bağımsızlıktan Günümüze Türkiye-Kırgızistan İlişkileri. İn M. Aydın (der.), Türkiye’nin Avrasya Macerası, 1989-2006 (pp. 401-436). Nobel Yayın Dağıtım , 1. Basım.

Gallarotti, G. M. (2011). Soft Power: What It Is, Why It's Important, and the Conditions for Its Effective Use, Journal of Political Power, 4(1).

Ghai, U. R. (2004). International Politics. Theory and Practice (10th ed.). New Academic Publishing, Jalandhar.

Grigoriadis, I. N. (2012). The Davutoğlu Doctrine and Turkish Foreign Policy. Bilkent University / ELIAMEP, April.

Hall, P. M. (1997). Meta-power, Social Organization and the Shaping of Social Action. SymbolicInteraction, 20, 397-418.

Hunter, S. (2001). Turkey, Central Asia, and the Caucasus: Ten Years after Independence. Southeast European and Black Sea Studies, 1(2), 1-16. http://dx.doi.org/10.1080/14683850108454634

Jenkins, G. (2007). Soft Power, Strategic Security, and International Philanthropy. North Carolina Law Review, $85,775$.

Justin Vela. Kyrgyzstan: Bishkek Detains Asylum-Seeking Turkish Terror Suspect. Retrieved May 19, 2011, from http://www.eurasianet.org/node/63522http://www.eurasianet.org/node/63522

Kegley, C. Jr., \& Wittkopf, E. R. (2010-2011). World Politics: Trend and Transformation. Belmont, CA: Thomson/Wadsworth.

Keles, I. (2009). Contributions of the Gülen Schools in Kyrgyzstan. Retrieved October 30, 2012, from http://www.fethullahgulen.org/conference-papers/contributions-of-the-gulen-movement/2467-contributionsof-the-gulen-schools-in-kyrgyzstan.html

Kurlantzick, J. (2007). Charm Offensive: How China's Soft Power Is Transforming the World. New Haven, CT: Yale University Press.

Kurtov, Ajdar. Russian Institute of Strategic Studies. Russian and Kazakh Experts on Kyrgyzstan Foreign Policy, 20.01.2012. Retrieved September 25, 2012, from at http://www.ipp.kg/ru/news/2212/

Larrabee, S. F., (2003). Turkish Foreign Policy in the Age of Uncertainty. RAND Corporation.

Manas University official. Retrieved from http://www.manas.kg/index.php/en/niversity/our-mission

March, J. G., \& Olsen, J. P. (2004). The Logic of aApropriateness. ARENA Working Papers WP. Retrieved October 30, 2012, from http://www.sv.uio.no/arena/english/research/publications/arena-publications/ workingpapers/working-papers2004/04_09.xml

Moldobaev, A. (2010). Kyrgyzstan's Foreign Policy and International -Political Problems of Turkey. 05.04.2010, Center of Prudent Solutions. Retrieved December 6, 2011, from http://www.analitika.org /article.php?story $=20100405041527787$

News Agency. Retrieved from http://easttime.info/news/kyrgyzstan/turkish-president-meets-kyrgyz-counterpart

Nye, J. (1990). Soft Power. Foreign Policy (No. 80). Twentieth Anniversary. http://dx.doi.org/10.2307/1148580

Nye, J. (2004). Soft Power: The Means to Success in World Politics. New York: Public Affairs.

Öniş, Z. (2010). Multiple Faces of the "New" Turkish Foreign Policy: Underlying Dynamics and a Critique. Glodem, Working Paper Series 04/2010, Koç University.

President Almazbek Atambaev speech in the Turkish Parliament. (in Russian), 13.01.2012. Retrieved from 
http://kabar.kg/rus/politics/full/25339.

Presidential web-site «Президенты Кыргызстана и Турции подписали юбилейную декларацию о новом историческом этапе отношений между двумя странами», 12.01.2012 . Retrieved April 5, 2012, from http://www.president.kg/ru/posts/4f0f5912f4d55210e9000001

Presidential web-site «Президенты Кыргызстана и Турции подписали юбилейную декларацию о новом историческом этапе отношений между двумя странами», 12.01.2012. Retrieved April 5, 2012, from http://www.president.kg/ru/posts/4f0f5912f4d55210e9000001

Press conference on annual activities of TURKPA, 17.04.2012. Retrieved October 27, 2012 from http://www.turk-pa.org/news.php?id=195\&lang=en

Press conference on annual activities of TURKPA. 17.04.2012. Retrieved October 27, 2012 from http://www.turk-pa.org/news.php?id=195\&lang=en

Program of the Turkey's Republican people Party (Cumhuriyet Halk Partisi Programı). Çağdaş Türkiye için Değişim.

Rose, G. (1998). Neoclassical Realism and Theories of Foreign Policy. World Politics, 51(1), 144-172. http://dx.doi.org/10.1017/S0043887100007814

Rothman, S. B. (2011). Revising the Soft Power Concept: What are the Means and Mechanisms of Soft Power? Journal of Political Power, 4(1), 49-64. http://dx.doi.org/10.1080/2158379X.2011.556346

Sari, Y. (2012). Foreign Policy of Kyrgyzstan under Askar Akayev and Kurmanbek Bakiyev. Perceptions, XVII(3), 131-150.

Sariev, Mars. Roundtable "Kyrgyzstan's Foreign Policy Priorities”, Institute for Public Policy, 12.04.2012, (in Russian). Retrieved May 5, 2012, from http://www.ipp.kg/ru/news/2326/

Semih, Ç., \& Sertkaya, B. (2011). An Analysis of Links between Turkey and Kyrgyzstan from Economic and Commercial Perspectives. Uluslararası Ticaret. Internatıonal Conference on Eurasian Economies (pp. 61-67).

Shestakov, I. (2012). Roundtable "Kyrgyzstan's Foreign Policy Priorities", Institute for Public Policy, 12.04.2012, (in Russian). Retrieved April 7, 2012, from http://www.ipp.kg/ru/news/2326/

Snyder, J. (2004). One World, Rival Theories. Foreign Policy, Nov/Dec, pp. 52-62. http://dx.doi.org $/ 10.2307 / 4152944$

Speaking very good Turkish. Atambavev noted that it means much from the perspective of showing support for the newly formed Kyrgyz government. Today's Zaman newspaper, 2 February 2011. Retrieved from http://www.todayszaman.com/news-234210-turkey-is-our-guiding-star-says-kyrgyz-prime-minister.html

Speech of Mr. Aitybai Tagayev, Speaker of Jogorku Kenesh of the Kyrgyz Republic at the First Plenary Session of TURKPA, 23.05.2012. Retrieved October 27, 2012 from http://www.turk-pa.org /news.php?id=430\&lang=en

Speech of Mr. Ramil Hasanov, TURKPA Secretary General, 25.06.2012. Retrieved October 27, 2012 from http://www.turk-pa.org/news.php?id=543\&lang=en

Tepperman, J. (2012, March). A Conversation with Abdullah Gul. Foreign Affairs. Istanbul. March 2012. Retrieved October 30, 2012, from http://www.foreignaffairs.com/discussions/interviews/turkeys -moment?page $=3 \&$ cid $=$ rss-author_interviews-turkeys_moment- 000000

The Embassy of the Kyrgyz Republic in Turkey official web-site. Retrieved from htttp://www.kgembassy.org.tr

The Ministry of Foreign Policy of the Republic of Turkey official. Retrieved from htttp://www.mfa.org.tr

Today's Zaman, 15 January 2012 / Today's Zaman, İstanbul. Retrieved from http://www.todayszaman.com /news-268649--kyrgyz-president-no-other-country-helped-us-like-turkey-did.html

Today's Zaman, newspaper, 2 February 2011. Retrieved from http://www.todayszaman.com/news -234210-turkey-is-our-guiding-star-says-kyrgyz-prime-minister.html. "Meclis’te ilk kez bir Türk konuştu !" 25 Ocak 2012. Retrieved from http://skyturkvngenc.wordpress.com/2012/01/25/turk-yurdunda -gecen-hafta/

Turkish Embassy. Org at Washington, DC. Retrieved Accessed September 12, 2003, from http://www.turkey.org /governmentpolitics/region-scentralasia.htm 
Turkish president meets Kyrgyz counterpart. Easttime Info Agency, October 1, 2012. Retrieved from http://easttime.info/news/kyrgyzstan/turkish-president-meets-kyrgyz-counterpart

Türkiye - Kırgızistan Siyasi İlişkileri. Türkiye Cumhuriyeti Dişişleri Bakanlığı. Retrieved August 14, 2012, from http://www.mfa.gov.tr/turkiye-kirgizistan-cumhuriyeti-siyasi-iliskileri.tr.mfa

Türkiye Cumhuriyeti Dişişleri Bakanlığı, "Türkiye - Kırgızistan Siyasi İlişkileri” [The Ministry of Foreign Affairs of Turkey, "Turkey-Kyrgyzstan Political Relations"] Retrieved from http://www.mfa.gov.tr /turkiye-kirgizistan-cumhuriyeti-siyasi-iliskileri.tr.mfa

Ulunyan, A. (2012). Center for Balkan, Caucasus and Central Asian Studies. Russian and Kazakh experts on Kyrgyzstan Foreign Policy, 20.01.2012. Retrieved September 25, 2012, from http://www.ipp.kg $/ \mathrm{ru} / \mathrm{news} / 2212 /$

Waltz, K. (1979). Theory of International Politics. New York: McGraw-Hill.

Waltz, K. (1986). Reflections on Theory of International Politics. A Response to My Critics. In R. O. Keohane (Ed.), Neorealism and Its Critics (pp. 322-345). New York: Columbia University Press.

Weitz, R. (2011). Turkish Foreign Policy in Evolution. Turkey Analyst, 4(21), 7.

Wohlforth, W. (1993). The Elusive Balance: Power and Perceptions during the Cold War. Ithaca, N.Y.: Cornell University Press.

Yanik, L. (2004). The Politics of Educational Exchange: Turkish Education in Eurasia. Europe-Asia Studies, 56(2), 293-307. http://dx.doi.org/10.1080/0966813042000190551

Yongtao, L. (2010). Discourse, Meanings and IR Studies (pp. 85-107). CONfines 6/11 enero-mayo 2010.

Zakaria, F. (1995). Realism and Domestic Politics. In M. E. Brown et al. (Eds.), The Perils of Anarchy: Contemporary Realism and International Security. Cambridge: MIT Press.

\section{Notes}

Note 1. In 2012, 82 states had their diplomatic missions in Kyrgyzstan (embassies, consulates, Charge D'Affaires). See http://www.mfa.kg/diplomatic-missions-in-kr/dip-in-kr-2_en.html

Note 2. Directed dyad is a perception of foreign policy in which the actor's foreign policy refers to specific goals with respect to another actor. Summed dyads is the dyadic relationships between various actors that is based upon their foreign policies and toward each other and the acts that are a result of those relationships. (Kegley \& Wittkopf, p.14)

Note 3. Giulio M. Gallarotti also underlines this point. (Giulio M. Gallarotti, p.33)

Note 4. For example, in the case of moral framing, one might suggest that preventing child labor in the world is the right thing to do because children are often unable to defend or speak for themselves in opposition to authority. A change in analytical framing occurred after failed states became an important cause of the creation of terrorist groups, whereas previously most failed states were ignored because of their lack of effects on more powerful states. (Rothman, 2011, p.54)

Note 5. At least looking at a number of official visits between heads of states.

Note 6. CCTS is an international organization comprising Turkic countries. It was founded on 3 October 2009 in Nakhchivan as an international intergovernmental organization, with the overarching aim of promoting comprehensive cooperation among Turkic Speaking States. The General Secretariat is in İstanbul, Turkey. The member countries are Azerbaijan, Kazakhstan, Kyrgyzstan and Turkey. The remaining two Turkic states, Turkmenistan and Uzbekistan are not currently official members of the council due to their neutral stance. However they are possible future members of the council. The idea of setting up this cooperative council was first put forward by Kazakh President Nursultan Nazarbayev back in 2006. (See CCTS official web-page at http://www.turkkon.org/eng/icerik.php?no=31)

Note 7. Both the United States and Russia saw Turkey as a secular state model comparing to Iran's model (non-secular) with its possible spreading ideology and influence in the region.

Note 8. For example, CHP was against increase of a number of Kyrgyz students studying in Turkey on the basis of scholarship. Also CHP was against the increase of the scholarships and students' monthly stipend. (Interview with official working in the Ministry of Education of Turkey. 03.05.2012, Ankara, Turkey) 
Note 9. Gulen's followers have built over 1,000 schools around the world. In the United States, his movement has 20,000 students in 130 charter schools. In Turkey Gulen's schools are considered among the best: expensive modern facilities, equal gender treatment and English taught from the first grade.

Note 10. Since April 2011 Turkey provided 30 million USD grant for maintenance of economy of Kyrgyzstan. Besides 51 million USD debt was written off. In June 2012 the bilateral agreement was signed according to which Turkey provides Kyrgyzstan credit 100 million USD for 20 years, and grace period is 7 years. (See $24 . \mathrm{kg}$ newspaper, available at http://www.24.kg/parlament/140428-olga-lavrova-kyrgyzstan-v-tekushhem-godu -poluchit.html).

\section{Copyrights}

Copyright for this article is retained by the author(s), with first publication rights granted to the journal.

This is an open-access article distributed under the terms and conditions of the Creative Commons Attribution license (http://creativecommons.org/licenses/by/3.0/). 